Kumawula, Vol. 4, No.1, April 2021, Hal 108 - 123

DOI: https://doi.org/10.24198/kumawula.v4i1.32361

ISSN 2620-844X (online)

Tersedia online di http://jurnal.unpad.ac.id/kumawula/index

\title{
PENGEMBANGAN USAHA UMKM DI MASA PANDEMI MELALUI OPTIMALISASI PENGGUNAAN DAN PENGELOLAAN MEDIA DIGITAL
}

\author{
${ }^{1 *}$ Sam'un Jaja Raharja, ${ }^{2}$ Sari Usih Natari \\ Departemen Ilmu Administrasi Bisnis Fakultas Ilmu Sosial dan Ilmu Politik Universitas Padjadjaran \\ *Korespondensi : s.raharja2017@unpad.ac.id
}

\begin{abstract}
The Covid-19 pandemic has hit many countries, including Indonesia. Covid-19 has had an impact in various sectors including Micro, Small and Medium Enterprises, including a decline in sales. Community Service Activities are carried out to provide guidance in overcoming these impacts through the use and management of appropriate digital media. By using and managing digital media, it is hoped that business actors can determine the right type of digital media for the product being marketed, increasing public awareness and interest regarding the product. The method used is virtual training using Zoom Meeting. The material for this activity is a strategy for the use and management of digital media, optimization of digital marketing and product branding to improve the ability to create interesting content, promotion and as an alternative media for service businesses. The digital media used include Instagram, Facebook, WhatsApp, GrabFood/Go-Food, Tokopedia and other platforms.

The results of the activity show that the training and guidance provided has a positive impact on business actors with an increase in knowledge about digital media, an increase in knowledge of various media that can be used and an increase in skills in the use and management of digital media in branding. Recommendations that can be conveyed are the existence of a sustainable development program for business actors so that they can implement and manage digital media optimally.
\end{abstract}

Keywords: MSMEs, Covid-19, social medial, digital media, digital marketing, branding

\begin{abstract}
ABSTRAK
Pandemi Covid-19 telah melanda banyak negara, termasuk Indonesia. Covid-19 telah menimbulkan dampak di berbagai sektor termasuk Usaha Mikro Kecil dan Menengah diantaranya yakni turunnya jumlah penjualan. Kegiatan Pengabdian Pada Masyarakat dilakukan untuk memberi bimbingan dalam mengatasi dampak tersebut melalui penggunaan dan pengelolaan media digital yang sesuai. Dengan menggunakan dan mengelola media digital, diharapkan para pelaku usaha dapat menentukan jenis media digital yang tepat untuk produk yang dipasarkan, meningkatkan awareness serta ketertarikan masyarakat mengenai produk. Metode yang digunakan adalah pelatihan secara virtual menggunakan Zoom Meeting. Materi kegiatan berupa ini adalah strategi penggunaan dan pengelolaan media digital, optimalisasi digital marketing serta branding produk untuk meningkatkan kemampuan pembuatan konten yang menarik, promosi serta sebagai media alternatif bagi pelaku usaha bidang jasa. Media digital yang digunakan antara lain Instagram, Facebook WhatsApp, GrabFood/Go-Food, Tokopedia dan platform lainnya.

Hasil kegiatan menunjukkan bahwa pelatihan dan bimbingan yang diberikan memberikan dampak positif bagi para pelaku usaha dengan adanya peningkatan pengetahuan tentang media digital, peningkatan pengetahuan berbagai media yang dapat digunakan dan adanya peningkatan keterampilan dalam penggunaan dan pengelolaan media digital dalam branding. Rekomendasi yang dapat disampaikan adalah adanya keberlanjutan program pembinaan bagi para pelaku usaha sehingga dapat menerapkan dan mengelola media digital secara optimal.
\end{abstract}

Kata kunci: UMKM, Covid-19, media sosial, media digital, pemasaran digital, branding 


\section{PENDAHULUAN}

Pandemi Covid-19 memberi dampak pada ketidakstabilan ekonomi, termasuk Usaha Mikro Kecil Menengah (UMKM). Secara umum, mayoritas dari pelaku UMKM mengalami penurunan pendapatan bahkan kebankrutan akibat pandemi Covid-19 (Sugiarti, Sari, \& Hadiyat, 2020). Menghadapi hal demikian diperlukan strategi bagi UMKM untuk tetap bertahan dan dapat mengembangkan bisnisnya di tengah pandemi Covid-19. Aspek utama yang sangat berdampak bagi pelaku UMKM salah satunya adalah penurunan jumlah penjualan yang membuat kondisi keuangan UMKM dalam kondisi krisis. Pembatasan kegiatan sosial membuat UMKM sulit untuk bergerak mengembangkan skala usaha jika hanya memanfaatkan metode konvensional tersebut. Pelaku usaha telah melakukan berbagai cara merespon kondisi sulit ini untuk mempertahankan usahanya.

Kurangnya mobilitas massa di sekitar pasar tentu menghambat laju promosi yang berpengaruh kepada tingkat penjualan. Mengatasi hal tersebut, pemasaran secara online melalui media merupakan langkah tepat yang harus dilakukan oleh para pelaku usaha (Suswanto \& Setiawati, 2020; Gu, Han, \& Wang, 2020).
Salah satu langkah yang dapat dilakukan oleh pelaku UMKM adalah dengan melakukan optimalisasi digital marketing terutama dalam sektor peningkatan social media marketing, online advertising, video marketing, search engine marketing, dan pengelolaan website. Dengan melakukan digitalisasi pemasaran, pelaku UMKM diharapkan dapat meningkakan penjualan dan online engagement untuk mengembangkan skala usaha di tengah pandemi Covid- 19. Nadya (2016) menjelaskan bahwa ketepatan dalam pemilihan media yang sesuai dengan perkembangan teknologi, sesuai dengan kecenderungan perilaku konsumen dalam media elektronik, dengan sendirinya memberikan opini yang menimbulkan pertimbangan bagi calon konsumen lain untuk melakukan pembelian.

Pandemi Covid-19 membatasi para konsumen untuk membeli produk UMKM secara langsung. Adanya pandemi ini juga menyebabkan banyaknya peraturan yang dikeluarkan oleh pemerintah, seperti larangan untuk berkerumun dan adanya Pembatasan Sosial Berskala Besar (PSBB). Kondisi tersebut menyebabkan para mitra kesulitan dalam melayani konsumen yang biasanya berkumpul di lapak para mitra UMKM. Tabel berikut ini beberapa dampak yang dialami oleh UMKM akibat PSBB.

Tabel 1 Dampak PSBB terhadap Kegiatan Bisnis

\begin{tabular}{|c|c|c|}
\hline No & Jenis Kebijakan & Bidang Usaha Terdampak \\
\hline 1 & Pengaturan jaga jarak fisik & $\begin{array}{l}\text { Salon kecantikan, barbershop, spa, perawatan } \\
\text { tubuh, }\end{array}$ \\
\hline 2 & Pengaturan jaga jarak sosial & Restoran, café, kantin, warung, rumah makan \\
\hline 3 & $\begin{array}{l}\text { Penutupan wilayah, pusat bisnis dan } \\
\text { perkantoran }\end{array}$ & $\begin{array}{l}\text { Perdagangan, makanan minuman, bengkel, } \\
\text { otomotif }\end{array}$ \\
\hline 4 & Penutupan kampus sekolah & $\begin{array}{l}\text { Fotocopy, ATK, warung jajanan, kantin sekolah, } \\
\text { baju seragam }\end{array}$ \\
\hline 5 & $\begin{array}{l}\text { Penutupan tempat wisata, rekreasi dan } \\
\text { travel }\end{array}$ & $\begin{array}{l}\text { Biro perjalanan, transportasi, kerajinan, } \\
\text { makanan, kaos suvenir }\end{array}$ \\
\hline 6 & Penutupan tempat ibadah & Busana muslim, perlengkapan ibadah \\
\hline 7 & Pelarangan acara pertemuan dan perayaan & $\begin{array}{l}\text { Event organizer, WO, katering, rias pengantin, } \\
\text { tata busana, sewa alat pesta, florist }\end{array}$ \\
\hline 8 & Penutupan mall, pusat hiburan & Fashion kasual, aksesoris, kafe, restoran \\
\hline 9 & Pelarangan kegiatan seni dan olahraga & $\begin{array}{l}\text { Sewa sarana, peralatan, perlengkapan dan baju } \\
\text { seni-olahraga }\end{array}$ \\
\hline
\end{tabular}

Sumber: Raharja \& Adiprihadi (2020) 
Berdasarkan berbagai permasalahan yang terjadi pada para mitra UMKM dapat disimpulkan bahwa mereka membutuhkan pendampingan maupun pelatihan dalam hal pemasaran digital/online dan cara branding produk para mitra ke pasar yang lebih luas. Branding produk serta strategi pemasaran yang baik sangat dibutuhkan dalam upaya meningkatkan kembali penjualan serta pendapatan para mitra UMKM. Maka dari itu, upaya yang dilakukan untuk mengembalikan serta meningkatkan penjualan serta pendapatan para mitra UMKM yakni dengan melakukan pendampingan serta pelatihan mengenai branding produk serta strategi pemasaran online/digital marketing (pemasaran pada platform online). Kegiatan pendampingan serta pelatihan tersebut dilakukan secara daring/online melalui Zoom Meeting.

Kondisi ini menjadi salah satu alasan untuk membantu memberdayakan pelaku UMKM dengan melakukan bantuan berupa pendampingan dalam pemanfaatan serta optimalisasi penggunaan media digital untuk melakukan promosi secara masif agar dapat memberikan dampak yang signifikan terhadap awareness target konsumen dengan harapan dapat meningkatkan penjualan produk mitra UMKM. Oktaviani dan Rustandi (2018) menyatakan bahwa digital marketing berperan dalam membangun brand awareness yang dilakukan dengan mengelola media sosial Instagram sebagai upaya membangun awareness.

Kegiatan ini bertujuan untuk (1) mengetahui kondisi dan permasalahan yang dialami para mitra UMKM (2) memberikan solusi dalam mengatasi permasalahan yang tengah dihadapi para mitra UMKM (3) membantu meningkatkan penjualan serta memperluas pasar para mitra UMKM melalui kegiatan pelatihan yang diberikan (4) memberikan usulan strategi marketing untuk mengatasi masalah yang dihadapi UMKM ditengah pandemi Covid-19.

Sedangkan manfaat bagi UMKM antara lain (1) UMKM dapat menggunakan dan mengelola media digital untuk meningkatkan usaha (2) menentukan jenis media sosial yang tepat serta sesuai dengan produk yang ingin dipasarkan melalui media digital meningkatkan awareness bagi masyarakat mengenai produk yang dijual oleh UMKM dan ketertarikan calon konsumen untuk melakukan pembelian produk (4) mengoptimalkan digital marketing untuk meningkatkan skala usaha (5) dapat memiliki pemahaman dan mengimplementasikan social media marketing, online advertising, dan photo/video editing (6) pelaku UMKM dapat meningkatkan brand engagement dari media sosial yang dimiliki dan dapat mengoptimalkan brand awareness melalui visual konten (7) meningkatkan skala bisnis mitra UMKM di masa pandemi (8) Memperluas tingkat edukasi pelaku bisnis UMKM tentang penggunaan teknologi digital dan pemasaran secara digital (9) UMKM memperoleh pengetahuan dan pemahaman mengenai branding produk serta pemasaran online (10) UMKM mendapat keterampilan tambahan mengenai cara mem-branding produk mereka serta pemasaran online untuk memperluas pasar (11) Dampak pelatihan diharapkan dapat meningkatkan penjualan produk dan pendapatan UMKM di masa pandemi Covid-19.

Hal ini sebagaimana dinyatakan oleh Yacub dan Mustajab (2020), digital marketing menggunakan Instagram dan Facebook memiliki pengaruh signifikan terhadap brand awareness.

Berdasarkan uraian permasalahan, kondisi yang dihadapi dan tujuan serta manfaat kegiatan, maka kegiatan ini dilaksanakan dengan judul "Pengembangan UMKM di Masa Pandemi Optimalisasi Penggunaan dan Pengelolaan Media Digital”.

Pelatihan diberikan kepada UMKM mitra yang menjadi subjek dalam pelaksanaan KKNM Integratif. Para peserta tersebar di 17 (tujuh belas) lokasi: Kota Bandung, Kabupaten Bandung, Kabupaten Bandung Barat, Sumedang, Kabupaten Sukabumi, Kota Bekasi, Kabupaten Bekasi, Kabupaten Bogor, Kabupaten Karawang, Kuningan, Tasikmalaya, Jakarta Timur, Kota Depok, Tangerang, Tangerang Selaatan, Jakarta Timur dan Jakarta Selatan 


\section{Konsep UMKM}

Menurut Rudjito (2003), UMKM adalah usaha yang membantu perekonomian Indonesia. Sebab melalui UMKM akan membentuk lapangan kerja baru dan meningkatkan devisa negara melalui pajak badan usaha. Kwartono (2007) menambahkan UMKM ialah kegiatan ekonomi rakyat yang memiliki kekayaan bersih maksimal Rp 200.000. 000,00 dimana tanah dan bangunan tempat usaha tidak diperhitungkan.

UMKM adalah unit usaha produktif yang berdiri sendiri, yang dilakukan oleh orang perorangan atau badan usaha di semua sektor ekonomi. Pada prinsipnya, pembedaan antara Usaha Mikro (UM), Usaha Kecil (UK), Usaha Menengah (UM), dan Usaha Besar (UB) umumnya didasarkan pada nilai aset awal (tidak termasuk tanah dan bangunan), omset rata-rata per tahun, atau jumlah pekerja tetap (Tambunan, 2012). Secara terperinci, konsep Usaha Mikro, Kecil dan Menengah (UMKM) mengacu kepada Undang-Undang Nomor 20 Tahun 2018 tentang UMKM, disajikan dalam tabel berikut;
Terkait dengan pandemi Covid-19, Han dan Nigg (2011) menyatakan bahwa UMKM kurang siap untuk mengelola risiko. UMKM, khususnya di negara berkembang tidak memiliki budaya dan sistem manajemen risiko maupun kelangsungan bisnis. Hal ini sejalan dengan yang dinyatakan oleh Liu et al. (2013) mengacu kepada krisis ekonomi 2008. Krisis ekonomi 2008 di seluruh dunia dan berdampak pada UMKM di hampir setiap negara menyebabkan penutupan UMKM secara besarbesaran, pengurangan skala dan jumlah usaha jumlah usaha baru. UMKM rentan terhadap risiko bencana di empat bidang: modal, tenaga kerja, logistik, dan pasar (Liu, Xu, \& Han, 2013)

Kossyva et al (2014) menambahkan bahwa hampir 50\% UMKM di Belgia dan Belanda, misalnya, mengalami keterlambatan dalam penerimaan pembayaran mereka (Kossyva, Sarri, \& Georgopoulos, 2014).

Tabel 2 Skala Usaha, Definisi dan Kriteria UMKM

\begin{tabular}{|c|c|c|c|}
\hline Skala Usaha & Definisi & Kriteria & Kuantitas Tenaga Kerja \\
\hline Usaha Mikro & $\begin{array}{l}\text { usaha produktif milik orang } \\
\text { perorangan dan/atau badan } \\
\text { usaha perorangan yang } \\
\text { memenuhi kriteria Usaha } \\
\text { Mikro sebagaimana diatur } \\
\text { dalam UndangUndang ini. }\end{array}$ & $\begin{array}{l}\text { a. Memiliki kekayaan bersih } \\
\text { paling banyak Rp. } \\
50.000 .000,00 \text { (lima puluh } \\
\text { juta rupiah) tidak termasuk } \\
\text { tanah dan bangunan tempat } \\
\text { usaha; atau } \\
\text { b. Memiliki hasil penjualan } \\
\text { tahunan paling banyak } \\
\text { Rp300.000.000,00 (tiga } \\
\text { ratus juta rupiah). }\end{array}$ & $<5$ orang \\
\hline Usaha Kecil & $\begin{array}{l}\text { usaha ekonomi produktif } \\
\text { yang berdiri sendiri, yang } \\
\text { dilakukan oleh orang } \\
\text { perorangan atau badan usaha } \\
\text { yang bukan merupakan anak } \\
\text { perusahaan atau bukan } \\
\text { cabang perusahaan yang } \\
\text { dimiliki, dikuasai, atau } \\
\text { menjadi bagian baik } \\
\text { langsung maupun tidak } \\
\text { langsung dari Usaha } \\
\text { Menengah atau Usaha Besar } \\
\text { yang memenuhi kriteria } \\
\text { Usaha Kecil sebagaimana } \\
\text { dimaksud dalam Undang- } \\
\text { Undang ini. }\end{array}$ & $\begin{array}{l}\text { a. Memiliki kekayaan bersih } \\
\text { lebih dari Rp50.000.000,00 } \\
\text { (lima puluh juta rupiah) } \\
\text { sampai dengan paling } \\
\text { banyak Rp500.000.000,00 } \\
\text { (lima ratus juta rupiah) tidak } \\
\text { termasuk tanah dan } \\
\text { bangunan tempat usaha; atau } \\
\text { b. Memiliki hasil penjualan } \\
\text { tahunan lebih dari } \\
\text { Rp300.000.000,00 (tiga } \\
\text { ratus juta rupiah) sampai } \\
\text { dengan paling banyak } \\
\text { Rp2.500.000.000,00 (dua } \\
\text { milyar lima ratus juta } \\
\text { rupiah). }\end{array}$ & $\begin{array}{l}\text { Jumlah tenaga kerja } 5 \\
\text { s.d } 19 \text { orang. }\end{array}$ \\
\hline
\end{tabular}




\begin{tabular}{|c|c|c|c|}
\hline Usaha Menengah & $\begin{array}{l}\text { usaha ekonomi produktif } \\
\text { yang berdiri sendiri, yang } \\
\text { dilakukan oleh orang } \\
\text { perorangan atau badan usaha } \\
\text { yang bukan merupakan anak } \\
\text { perusahaan atau cabang } \\
\text { perusahaan yang dimiliki, } \\
\text { dikuasai, atau menjadi } \\
\text { bagian baik langsung } \\
\text { maupun tidak langsung } \\
\text { dengan Usaha Kecil atau } \\
\text { Usaha Besar dengan jumlah } \\
\text { kekayaan bersih atau hasil } \\
\text { penjualan tahunan } \\
\text { sebagaimana diatur dalam } \\
\text { Undang- Undang ini. }\end{array}$ & $\begin{array}{lr}\text { a. Memiliki kekayaan bersih } \\
\text { lebih dari Rp500.000.000,00 } \\
\text { (lima ratus juta rupiah) } \\
\text { sampai dengan paling } \\
\text { banyak } \\
\text { Rp10.000.000.000,00 } \\
\text { (sepuluh milyar rupiah) tidak } \\
\text { termasuk tanah dan } \\
\text { bangunan tempat usaha; atau } \\
\text { b. Memiliki hasil penjualan } \\
\text { tahunan lebih dari } \\
\text { Rp2.500.000.000,00 (dua } \\
\text { milyar lima ratus juta rupiah) } \\
\text { sampai dengan paling } \\
\text { banyak Rp } \\
\text { 50.000.000.000,00 (lima } \\
\text { puluh milyar rupiah). }\end{array}$ & $\begin{array}{l}\text { Jumlah tenaga } \\
\text { kerja } 20 \text { s.d. } 99 \text { orang. }\end{array}$ \\
\hline
\end{tabular}

Sumber: Undang-Undang Nomor 20 Tahun 2018 tentang UMKM

Pengangguran struktural yang tinggi juga menurunkan permintaan barang dan layanan memberikan dampak bagi UMKM secara signifikan (Alegre \& Chiva, 2013). Kejadian bencana juga dapat merusak dan mengganggu jaringan rantai pasokan dimana banyak UMKM terlibat. Risiko tersebut menurunkan nilai aset, mengganggu operasional, meningkatkan biaya produksi dan mengurangi pendapatan serta potensi pertumbuhan jangka panjang (Linnenluecke \& Griffiths, 2010).

Sektor lain yang berdampak pada UMKM adalah industri pariwisata. Industri ini merupakan salah satu industri yang terdampak oleh penyebaran Covid-19. Di Bali telah terjadi 40.000 pembatalan hotel dengan kerugian mencapai 1 triliun rupiah setiap bulan (Pratiwi, 2020) Lesunya sektor pariwisata memiliki efek domino terhadap sektor UMKM. Berdasarkan data yang diolah P2E LIPI, dampak penurunan pariwisata terhadap UMKM yang bergerak dalam usaha makanan dan minuman mikro mencapai $27 \%$. Sedangkan dampak terhadap usaha kecil makanan dan minuman sebesar $1,77 \%$, dan usaha menengah di angka $0,07 \%$. Pengaruh virus Covid-19 terhadap unit kerajinan dari kayu dan rotan, usaha mikro akan berada di angka $17,03 \%$. Untuk usaha kecil di sektor kerajinan kayu dan rotan $1,77 \%$ dan usaha menengah $0,01 \%$. Sementara itu, konsumsi rumah tangga juga akan terkoreksi antara $0,5 \%$ hingga $0,8 \%$ (Pratiwi, 2020).
Sementara itu, Kementerian Koperasi UKM menyatakan bahwa dari seluruh UMKM yang terdata di Kemenkop UKM, dilaporkan sejumlah 56\% UMKM mengaku mengalami penurunan pada hasil omzet penjualan akibat pandemi Covid-19, 22\% lainnya mengalami kesulitan dalam mendapatkan pembiayaan/kredit, $\quad 15 \% \quad$ mengalami permasalahan dalam distribusi barang, dan $4 \%$ sisanya melaporkan kesulitan mendapatkan bahan baku mentah. Seluruh UMKM yang terdata dalam riset ini, komposisi UMKM yang bergerak dalam industri mikro menempati angka 87,4\% (Mahmud, 2020).
Meskipun
pandemi
Covid-19 memunculkan beberapa masalah, di sisi lain ada kesempatan yang juga muncul. Banyak UMKM dan koperasi bisamemanfaatkan teknologi informasi dan komunikasi mengingat perdagangan elektronik pada 2020 mencapai US\$ 130 miliar. Transaksi perdagangan elektronik meningkat secara drastis, antara lain produk kesehatan meningkat $90 \%$, produk penunjang hobi naik $70 \%$, makanan naik $350 \%$, dan makanan herbal naik 200\% (Amri, 2020).

\section{Media Online}

Media online disebut juga dengan digital media adalah media yang tersaji secara online di internet. Pengertian media online secara umum, yaitu segala jenis atau format media yang hanya bisa diakses melalui internet berisikan teks, foto, video, dan suara (Irwansyah, 2011). Dalam pengertian umum 
ini, media online juga bisa dimaknai sebagai sarana komunikasi secara online. Dengan pengertian media online secara umum ini, maka email, mailing list (milis), website, blog, Whatsapp, dan media sosial masuk dalam kategori media online.

Media online adalah sebutan umum untuk sebuah bentuk media yang berbasis telekomunikasi dan multimedia. Didalamnya terdapat portal, website (situs web), radioonline, $\mathrm{TV}$-online, pers online, mail-online, dan lain-lain, dengan karakteristik masing-masing sesuai dengan fasilitas yang memungkinkan user memanfaatkannya.

Media online memiliki beberapa kekuatan yang tidak dimiliki oleh media cetak dan media elektronik (McLuhan, 2011), yaitu :

a) Terdapat link untuk menawarkan pengguna (user) dalam membaca informasi secara online.

b) Konsumen dapat melihat informasi baru secara up to date.

c) Informasi dapat diperbaharui secara luas secara online.

d) Terdapat fitur membuat konten, foto, video dan suara yang mudah secara online.

e) Dapat menyimpan data secara online tanpa terbatas waktu.

Penggunaan internet yang mulai merambah berbagai kalangan dapat membuat orang-orang banyak menghabiskan waktu secara virtual (McQuail, 2011). Hal ini menyebabkan media secara online mulai banyak mengembangkan platform-platform baru dalam memenuhi kebutuhan masyarakat, seperti chat room, game online, dan lain sebagainya.

\section{Media Sosial}

Menurut Zarella (2011), media sosial merupakan paradigma media baru dalam konteks industri pemasaran. Sedangkan menurut Asmaya (2015) media sosial merupakan platform yang mampu membantu dan memfasilitasi berbagai kegiatan seperti mengintegrasikan situs web, interaksi sosial, dan pembuatan konten berbasis komunitas. Kehadiran media sosial menandakan pergeseran arah dalam penggunaan media komunikasi yang sekarang serba berbasis internet dan bisa memfasilitasi saluran akses beragam bidang (Susanti, Gunawan, \& Sukaesih, 2019).

Penggunaan media sosial dapat memfasilitasi seperti konten, komunikasi dan percakapan. Platform media sosial dapat di kelompokan kedalam beberapa kategori besar:

- Publikasi Web: (a) Microbologging (Twitter, Phurk), (b) Blogs (Wordpress, Blogger), (c) Wiki (Wikispaces, PBwiki) dan (d) Mashup (Googel Maps, Popurls).

- Jejaring sosial

Aplikasi yang memungkinkan pengguna untuk membuat dan membangun koneksi dengan berabagai informasi pengguna lainya. Ada beberapa platform. Umumnya jaringan sosial sebagi berikut: (a) Alat media sosial (Facebook, Linkedin, Google) (b) Social Bookmark (Delicious, Digg), (c) Virtual Words (Second Life, Opensim), (d) Crowdsourcing/social voting (Ideascale, chaordix).

\section{- File Sharing dan Penyimpanan}

Sebuah layanan hosting file atau penyediaan penyimpanan file secara online yang di rancang khusus untuk menyimpan konten. Platform untuk menyipan file meliput; (a) Pepustakaan foto (flickr, Picasa) (b) Video Sharing (YouTube, Vimeo), (c) Audio Sharing (Podcast, Itunes), (d) Penyimpanan (Google Documents, Drop.io, Myspace) (e) Manajemen Konten (Sharepoint, Drupal).

\section{Pemasaran Digital}

Pemasaran digital adalah pemasaran menggunakan internet sebagai media pemasaran. Pemasaran digital sangat membantu UMKM karena kemampuan baru konsumen dalam mengikuti arus digitialisasi. Dengan adanya digital marketing komunikasi dan transaksi dapat di lakukan setiap waktu atau real time dan bisa diakses di seluruh dunia, serta seseorang juga dapat melihat berbagai barang melalui internet. Sebagian besar sebuah informasi mengenai berbagai produk sudah tersedia di internet dalam kemudahan pemesanan dan kemampuan konsumen dalam membandingkan sebuah produk dengan produk lainnya. 
Menurut Kotler (2018) pemasaran online (e-marketing) adalah saluran yang dapat dijangkau seseorang melalui komputer dan modem. Modem menghubungkan komputer dengan jalur telepon sehingga komputer menjangkau beragam layanan informasi online. Sedangkan menurut Bala (2018) e-marketing adalah melakukan bisnis online yang bentuknya paling jelas adalah menjual produk kepada konsumen secara online. .

Menurut Irmawati (2011) model bisnis dalam layanan bisnis online (e-marketing) terbagi atas 6 (enam) jenis, antara lain:

a) Connectivity

Bisnis yang berbasis layanan akses internet kepada pelanggannya.

b) Context

Bisnis yang memberikan layanan dengan berupa informasi dan hiburan.

c) Content

Bisnis yang memberikan layanan dengan basis berupa teks atau gambar sebagai inti bisnisnya.

d) Communication

Layanan komunikasi berbasis internet dengan menggunakan media interaktif.

e) Community

Bisnis yang membngun komunitas digital dengan media message, board, web chat, maupun penyedia web mail.

\section{f) Commerce}

Model bisnis yang melakukan aktivitas bisnis berbasis internet.

Pemasaran digital yang semakin berkembang dan berkaitan erat dengan media sosial sangat mempermudah konsumen mendapatkan informasi yang diinginkan. Instagram merupakan salah satu media sosial yang masuk dalam kategori jejaring sosial yang dapat diakses dengan mudah, dan dapat memberikan informasi.

\section{METODE}

Menurut Murdjito (2012) metode penbadian pada masyarakat ialah suatu pola sistim Tindakan yang akan dilakukan, ataupun urutan atau tahapan-tahapan yang perlu dalam menjalankan kegiatan pengabdian masyarakat
Selanjutnya Murdjito (2012) menambahkan tahapan-tahapan yang perlu diikuti yaitu: (1) analisis situasi masyarakat (2) identifikasi masalah (3) menentukan tujuan kerja (4) rencana pemecahan masalah (5) pendekatan sosial (6) pelaksanaan kegiatan (7) evaluasi kegiatan dan hasil. Mengacu kepada pendapat Murdjito tersebut maka metode dan tahapan kegiatan diuraikan sebagai berikut;

1) Analisis situasi dalam bentuk kegiatan awal dengan melakukan analisis situasi UMKM di masa pandemi. Dalam hal ini dilakukan analisis situasi dan pengamatan terhadap dampak pandemi terhadap kondisi mitra UMKM.

2) Identifikasi masalah yaitu dengan mengidentifikasi permasalahanpermasalahan apa saja yang dihadapi oleh UMKM terkait dengan kegiatan atau aktivitas bisnis mereka selama pandemi. Lingkup identifikasi mengacu kepada 4 (empat) fungsi utama bisnis yaitu: pemasaran, keuangan, produksi dan sumberdaya manusia. Hasil identifikasi masalah mengerucut kepada permasalahan utama mitra UMKM yaitu menurunnya penjualan produk maupun jasa. Secara teoritis masalah penjualan merupakan bagian dari pemasaran. Dengan demikian, masalah utama mitra UMKM adalah masalah pemasaran.

3) Menentukan tujuan kerja yaitu menentukan apa yang ingin dicapai dari atau perubahanperubahan yang ingin dihasilkan melalui kegiatan in. Dalam hal ini tujuan kerja adalah meningkatkan Kembali aktivitas bisnis mitra UMKM khususnya penjualan yang mengalami penurunan karena adanya wabah pandemi Covid-19.

4) Rencana pemecahan masalah terkait dengan bentuk kegiatan pengabdian pada masyarakat (PPM). Sebetulnya banyak sekali bentuk PPM seperti KKN, desa binaan, Pengabdian Lingkar Kampus (PLK), kerjasama, kemitraan, pelatihan dan lain-lain. Berkaitan dengan kegiatan pengembangan UMKM di masa Pandemi, bentuk kegiatan sebagai pemecahan masalah adalah pelatihan. 
5) Pendekatan sosial, dalam hal ini berupa perlakuan terhadap mitra sebagai subjek kegiatan. Hal ini dikarenakan masalah yang akan dipecahkan adalah masalah yang dihadapi oleh mitra berupa lesunya usaha yang ditandai dengan menurunnya penjualan dan lain. Dalam pendekatan sosial ini mitra UMKM benar-benar dilibatkan dalam perencanaan kegiatan melalui pendekatan personal terhadap mitra dalam bentuk pengisian formulir, wawancara dan beberapa diantaranya berdialog secara langsung

6) Pelaksanaan kegiatan, dalam hal ini adalah kegiatan pelatihan pemasaran. Mengingat dalam suasana pandemi Covid-19, maka kegiatan dilaksanakan secara virtual/online. Waktu pelaksanaan ditetapkan pada minggu ke-4 Januari. Karena dilaksanakan secara daring, maka narasumber maupun peserta berada di lokasi masing-masing. Dalam kegiatan ini pihak yang terlibat adalah narasumber, peserta dan Tim pelaksana yaitu mahasiswa peserta KKNM periode Januari-Februari 2021

Mengacu kepada identifikasi masalah, maka masalah utama mitra UMKM adalah masalah pemasaran. Hasil identifikasi bahwa semua mitra mengalami kesulitan dalam hal penjualan, menurunnya volume penjualan dan tidak adanya konsumen. Sementara mengacu kepada tujuan kerja adalah meningkatkan kembali aktivitas bisnis melalui penjualan atau pemasaran, maka pemecahan masalah yang dipilih adalah pelatihan yang terkait dengan pemasaran dalam bentuk bagaimana meningkatkan penjualan. Dengan demikian pemecahan masalahnya adalah dengan mengadakan pelatihan pemasaran melalui alternatif strategi pemasaran. Dalam hal ini penggunaan media sosial merupakan salah satu saluran pemasaran yang dinilai dapat efektif dalam memasarkan produk..

Pelatihan diberikan dalam bentuk dengan pemberian edukasi bagi mitra UMKM yang sesuai dengan kebutuhan atau yang diinginkan oleh mitra peserta kegiatan. Pelatihan diberikan kepada 40 (empat puluh) mitra yang tersebar di berbagai daerah. Kegiatan pelaksanaan dilakukan secara kombinasi (hybrid) melalui tatap muka dengan menerapkan protokol Kesehatan yang ketat dan melalui Zoom (daring).

Secara garis besar tema yang disampaikan kepada khalayak adalah sebagai berikut

- Digital Marketing dan Promosi melalui media digital

- Pemanfaatan Teknologi Digital sebagai Alat Pengembangan dan Pemasaran

- Strategi Pemasaran: Branding dan Digitalisasi Produk, Identitas Produk

7) Evaluasi

Pasca pelatihan dan bimbingan, dilakukan evaluasi terhadap mitra untuk melihat respons dan manfaat dari hasil pelatihan dan bimbingan tersebut serta adanya peningkatan baik pengetahuan maupun keterampilan dari para mitra UMKM. Selain itu juga untuk menilai tingkat pemahaman dan kepuasan dari pelatihan. Evaluasi juga untuk melihat apakah ada dampak dari pemberian pelatihan tersebut dan dapat menciptakan inovasi secara mandiri setelah diberikan pelatihan.

\section{HASIL DAN PEMBAHASAN}

\section{Gambaran Kondisi dan Tingkat Pengetahuan Peserta Sebelum Pelatihan}

Khalayak sasaran kegiatan ini tersebar di berbagai wilayah yakni di Bandung, Sumedang dan Jabodetabek sesuai dengan domisili masing-masing mitra. Mitra yang menjadi khalayak sasaran sebanyak 40 (empat puluh) orang berada di tempat tinggal atau tempat usaha masing-masing. Pada bagian ini mendeskripsikan gambaran umum kondisi dan tingkat pengetahuan para mitra UMKM di daerah masing-masing.

\section{a. Media sosial yang diketahui mitra}

Salah satu kekuatan pendorong terdepan dan pembangunan ekonomi di Indonesia adalah pengembangan UMKM di setiap daerah Indonesia. Dalam membantu pengembangan UMKM tersebut dapat dibantu dengan adanya media sosial yang menjadi trend tahun 2021 ini. Hal ini 
diakibatkan adanya pencegahan Covid19 yang masih tinggi dan perkembangan digital yang semakin digemari masyarakat. Untuk itu, perlu melakukan survei terkait pengetahuan media sosial yang dimiliki oleh pelaku UMKM beberapa daerah di Indonesia dengan kegiatan PPM ini. perusahaan sehingga tujuan untuk meningkatkan penjualan diharapkan dapat tercapai.

\section{b. Media sosial yang digunakan mitra} UMKM

Pengertian media online secara umum, yaitu segala jenis atau format media yang hanya bisa diakses melalui

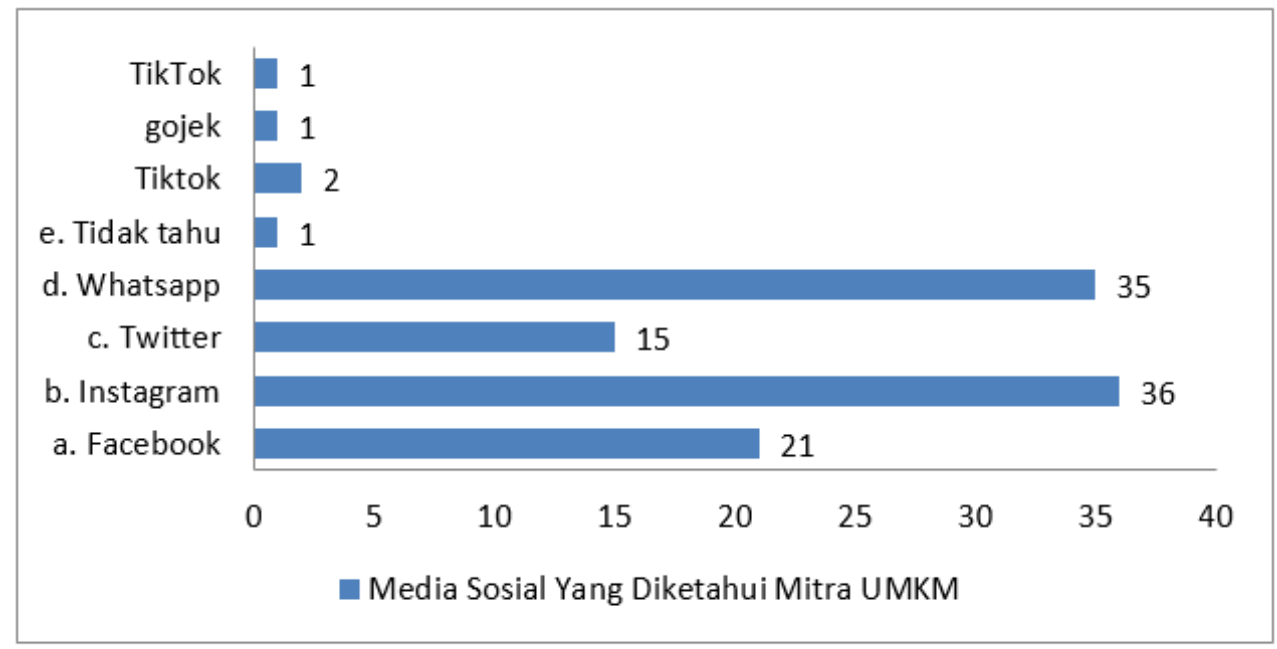

\section{Gambar 1. Media Sosial Yang Diketahui Mitra UMKM}

Berdasarkan hasil survei diatas, dapat diketahui bahwa media sosial yang diketahui mitra UMKM di beberapa daerah di Indonesia adalah Instagram. Instagram sendiri sering digunakan sebagai sarana promosi untuk meningkatkan minat beli konsumen. Hal ini sesuai dengan strategi promosi yaitu membujuk, merangsang konsumen agar mau membeli produk internet berisikan teks, foto, video, dan suara. Dengan pengertian media online secara umum ini, maka email, mailing list (milis), website, blog, whatsapp, dan media sosial masuk dalam kategori media online. Khusus media sosial yang sering digunakan oleh masyarakat Indonesia memiliki instensitas cukup tinggi dibandingkan media online lainnya. Media sosial tersebut yaitu

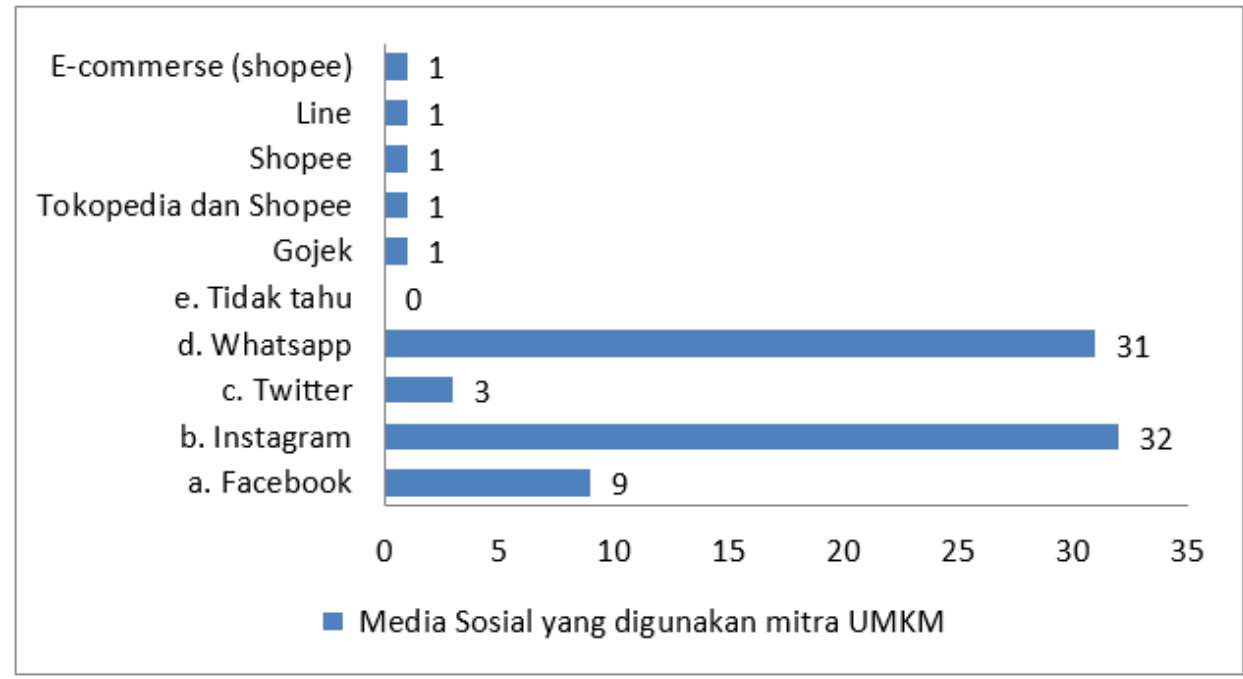

Gambar 2. Media Sosial Yang Digunakan Mitra UMKM 
Instagram, TikTok, Beetalk, Facebook, Twitter dan lain sebagainya.

Berdasarkan hasil survei di atas, dapat diketahui bahwa media sosial yang digunakan mitra UMKM tertinggi adalah Instagram. Instagram merupakan media informasi yang dapat dengan mudah menampilkan foto yang digunakan mitra UMKM. Fitur foto dalam Instagram pun memiliki banyak desain menarik untuk diedit, dengan tujuan agar konsumen tertarik untuk membeli produk yang dijual oleh mitra UMKM. Hal ini sesuai dengan media sosial yang diketahui oleh para mitra UMKM sebelumnya, yaitu Instagram. Sehingga kegiatan bisnis para mitra UMKM lebih banyak menggunakan Instagram.

c. Hal penting yang harus ada dalam media sosial

Media online disebut juga dengan digital media adalah media yang tersaji secara online di internet. Dalam pengertian umum ini, media online juga bisa dimaknai sebagai sarana komunikasi secara online. Salah satunya adalah media sosial yang menjadi tren akhir-akhir ini. Namun ada beberapa hal penting yang harus diperhatikan dalam menggunakan media sosial, yaitu profil usaha, bahasa yang menarik, foto, kualitas produk dan kemasan produk.
Berdasarkan hasil survei di atas, dapat diketahui bahwa hal penting yang harus ada dalam media sosial oleh mitra UMKM adalah foto. Foto merupakan hal penting visual tersirat dalam menyampaikan informasi produk kepada konsumen. Gambar yang menarik dalam foto menjadi kunci penting dalam menarik konsumen dalam penjualanan yang dilakukan oleh mitra UMKM. Foto produk dari para mitra UMKM dimasukkan ke dalam media sosial yang sering digunakan yaitu Instagram. Di mana hal ini sesuai dengan pernyataan sebelumnya, Instagram sering digunakan dalam kegiatan bisnis para mitra UMKM.

d. Manfaat media sosial yang digunakan mitra UMKM

Salah satu desain media online yang paling umum diaplikasikan dalam praktik jurnalistik modern dewasa ini adalah berupa situs berita. Media sosial merupakan paradigma media baru dalam konteks industri pemaasaran. Penggunaaan media sosial juga menjadi media digital marketing tertinggi pada tahun 2021. Manfaat yang dihasilkan dari penggunaan media sosial sangat banyak dan beragam. Diantaranya adalah meminimalisasi biaya operasional, memudahkan transaksi, menguntungkan, memudahkan penjualan, hemat tempat,

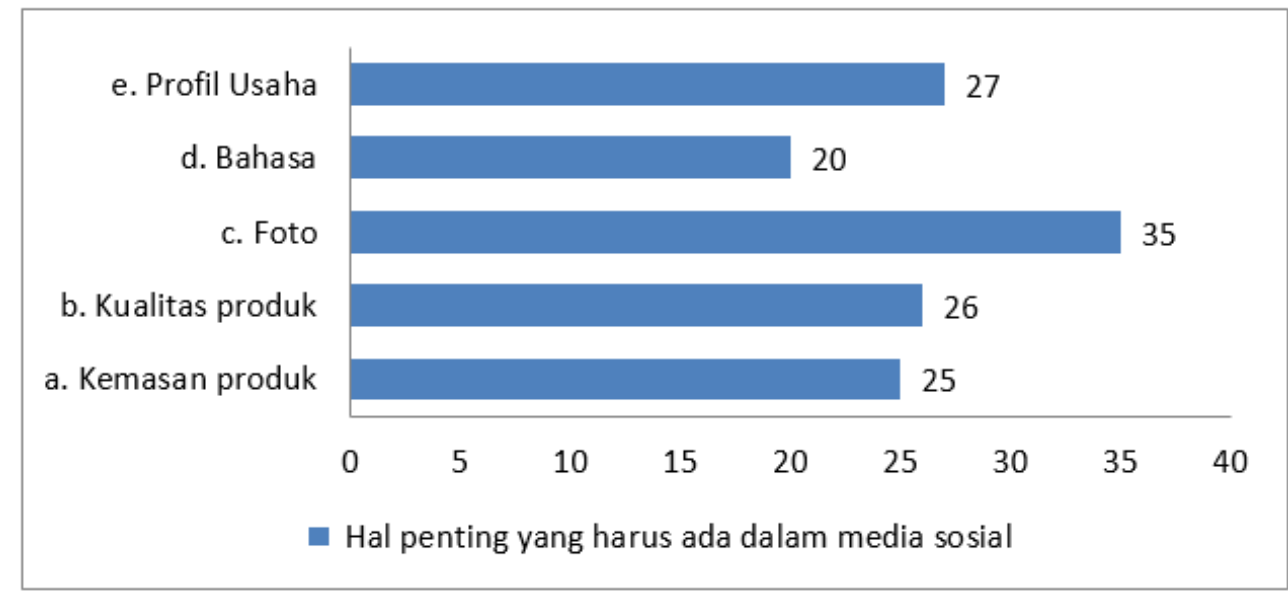

Gambar 3. Hal Penting Yang Harus Ada Dalam Media Sosial 
sistem serba online dan mempermudah

promosi.

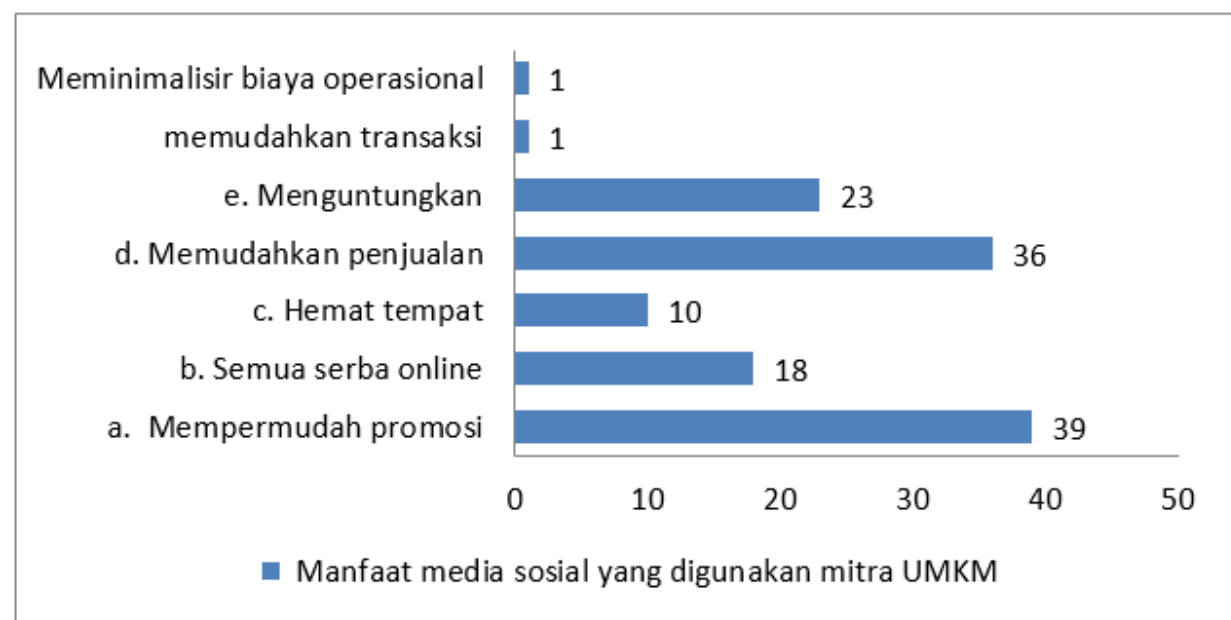

Gambar 4. Manfaat Media Sosial Yang Digunakan Mitra UMKM

Berdasarkan hasil survei di atas, dapat diketahui bahwa manfaat media sosial yang dirasakan dan digunakan oleh mitra UMKM tertinggi adalah bertujuan untuk mempermudah promosi. Selain mudah dan ekonomis dalam promosi, media sosial juga memiliki fitur-fitur desain menarik dalam menggapai target konsumen lebih banyak dibandingkan secara konvensional. Ditambah lagi masyarakat era 2021 ini, sudah banyak mengenal digital dan gadget yang menjadi kebutuhan sehari-hari. Sehingga promosi sering dilakukan dalam media sosial oleh para mitra UMKM, seperti Instagram, Whatsapp dan Facebook. e. Hal penting dalam pengelolaan media sosial yang digunakan mitra UMKM

Media sosial merupakan platform yang mampu membantu dan memfasilitasi berbagai kegiatan seperti mengintegrasikan situs web, interaksi sosial, dan pembuatan konten berbasis komunitas. Begitu banyaknya media sosial seiring perkembangan jaman hingga tahun 2021 ini, maka fitur konten yang ditampilkan pun beragam. Kata-kata yang digunakan, waktu saat memposting, postingan yang menarik, foto yang menarik dan tampilan profil usaha.

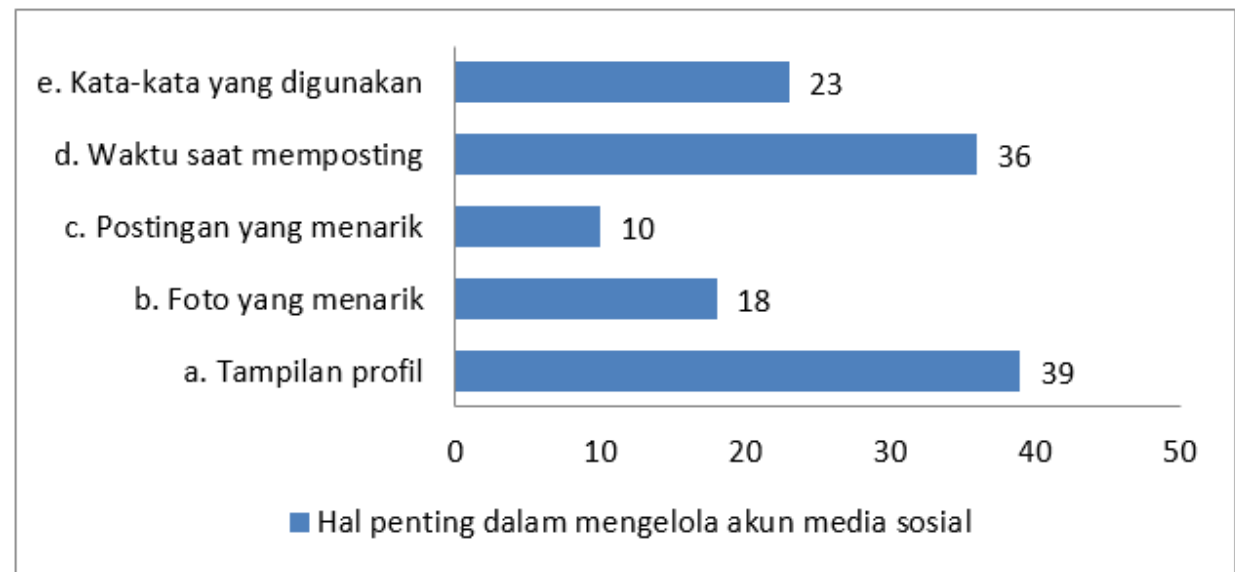

Gambar 5. Hal Penting Dalam Mengelola Akun Media Sosial 
Berdasarkan hasil survei di atas, dapat diketahui bahwa konten dalam pembuatan media sosial yang digunakan oleh mitra UMKM tertinggi adalah tampilan profil. Tampilan profil ini menjadi sangat penting bagi mitra UMKM karena dapat mewakilkan identitas terhadap usaha yang akan di promosikan melalui media sosial. Setelah itu, waktu saat memposting menjadi langkah kedua yang cukup penting bagi mitra dalam memberikan informasi update kepada konsumen.

Tampilan profil yang dilakukan oleh para mitra UMKM, sering menggunakan Instagram sebagai media sosialnya. Di mana Instagram memiliki kemudahan dalam mendesain fitur profil dan menampilkan update produk dari para mitra UMKM. Hal ini sesuai dengan pengetahuan dan intensitas penggunaan media sosial yang sering digunakan oleh para mitra.

\section{Analisis Dampak Pelatihan}

Pembahasan selanjutnya adalah bagaimana dampak yang terjadi atas pemberian pelatihan dan pendampingan yang dilakukan setelah pelaksanaan pelatihan. Analisi meliputi peningkatan pengetahuan dan keterampilan, peningkatan pemasaran dan hal lainnya yang berkaitan

\section{a. Peningkatan pengetahuan dan keterampilan mitra}

Evaluasi dari kegiatan ini selama sebulan ini dapat dilihat dari adanya peningkatan pengetahuan dan keterampilan mitra setelah pelatihan pengembangan UMKM. Pengetahuan tersebut dapat dirasakan menambah wawasan dari mitra UMKM masing-masing.

Berdasarkan hasil evaluasi dampak di atas, dapat diketahui bahwa peningkatan pengetahuan dan keterampilan mitra setelah pelatihan pengembangan UMKM ini dirasakan sangat baik. Hal ini terbukti sebesar $48,78 \%$ memilih skala 5 dalam peningkatan pengetahuan dan keterampilan mitra setelah dilakukan pelatihan. Peningkatan pengetahuan dan keterampilan tersebut berupa penggunaan media sosial untuk bisnis, yaitu Instagram Ads, Whatsapp Business dan Facebook khusus akun bisnis. Selain itu, banyak juga pengetahuan dan keterampilan yang berhasil meningkatkan keterampilan yang diperoleh para mitra UMKM yaitu penggunaan e-commerce dan ojek online (Gojek dan Grab) yang dapat menunjang bisnis para mitra UMKM.

b. Dampak pemasaran dan penjualann yang dirasakan oleh mitra UMKM

Strategi pemasaran dan penjualanan memiliki tujuan untuk membujuk, merangsang konsumen agar mau membeli produk perusahaan sehingga tujuan untuk meningkatkan penjualan diharapkan dapat tercapai. Sehingga dampak yang dihasilkan

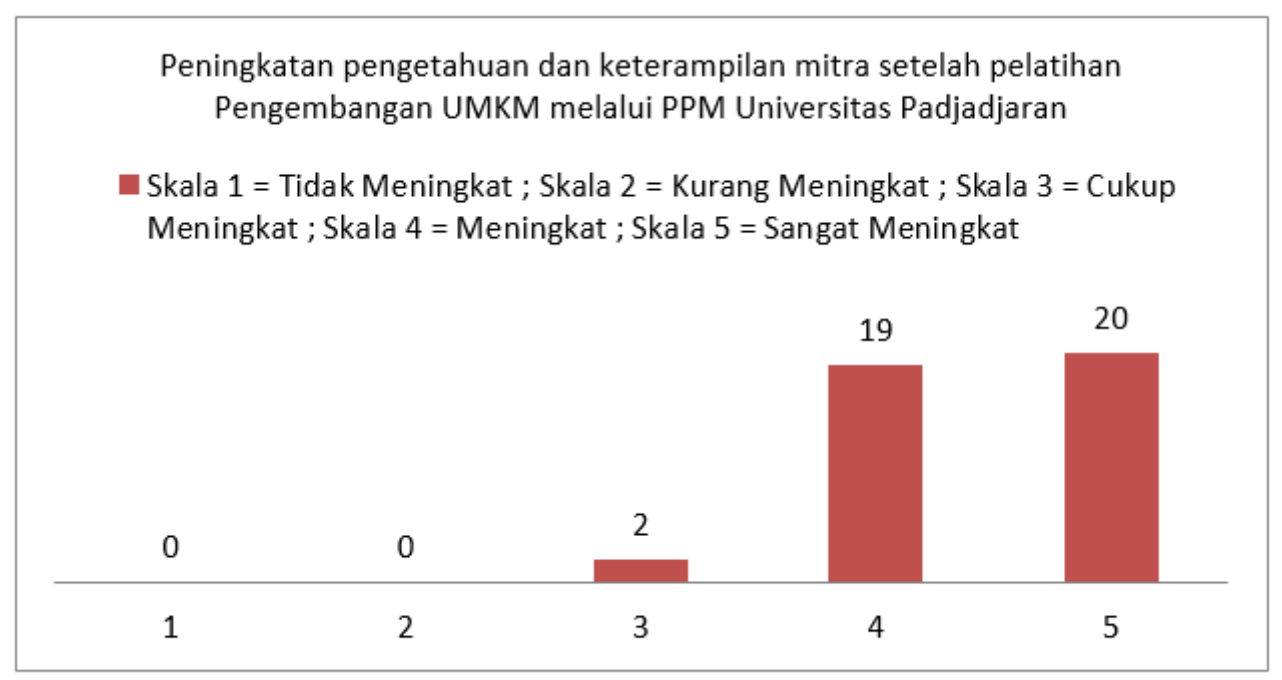

Gambar 6. Peningkatan pengetahuan dan keterampilan mitra 
diharapkan dapat meningkatkan penjualanan produk yang dihasilkan oleh para mitra UMKM.

\section{c. Tingkat Kepuasan mitra terhadap solusi melalui Pelatihan}

Pemasaran merupakan sistem kegiatan bisnis yang dirancang untuk merencanakan,

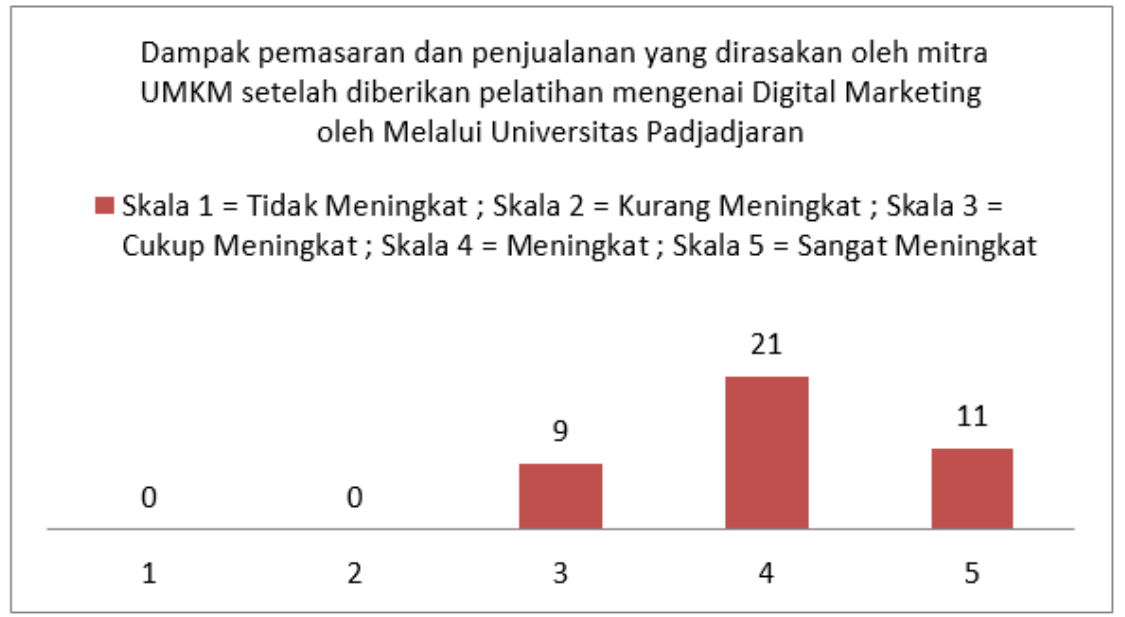

\section{Gambar 7. Dampak Pemasaran dan Penjualan Pasca Pelatihan Digital Marketing}

Berdasarkan hasil evaluasi di atas, dapat diketahui bahwa sebesar 51,21\% memilih skala 4. Di mana dampak yang dirasakan setelah diberikan pelatihan mengenai digital marketing dapat meningkatkan pemasaran dan penjualan produk oleh para mitra UMKM. Pelatihan digital marketing yang diberikan salah menentukan harga, promosi, dan mendistribusikan barang yang dapat memuaskan keinginan dan mencapai target pasar dan sesuai dengan tujuan bisinis perusahaan. Kepuasan tersebut dapat membuat dan membangun koneksi dengan berbagai informasi pengguna lainnya terhadap produk yang dimiliki oleh mitra UMKM.

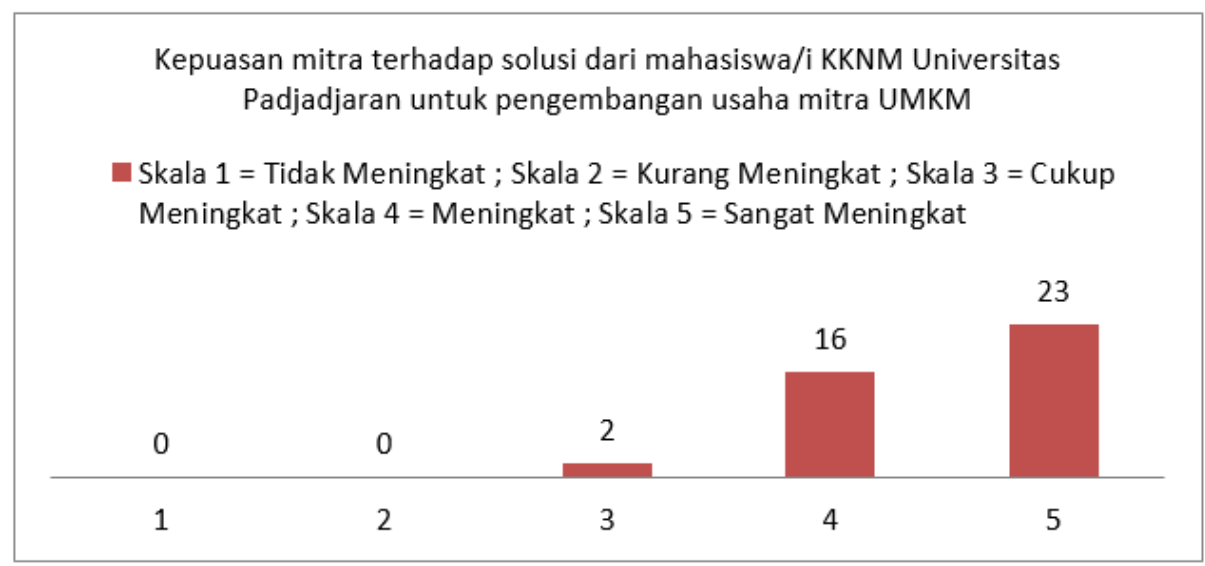

Gambar 8. Kepuasan Mitra terhadap Solusi Melalui Pelatihan PPM

satunya adalah dengan edukasi penggunaan Instagram Ads, Whatsapp Business dan Ojek Online (Go-jek dan Grab). Dampak tersebut berupa manfaat dari penggunaan media sosial, yaitu meminimalisasi biaya operasional, memudahkan transaksi, menguntungkan, memudahkan penjualanan, hemat tempat, sistem serba online dan mempermudah promosi.
Berdasarkan hasil evaluasi di atas, dapat diketahui bahwa sebesar 56,09\% memilih skala 5. Hal ini berarti kepuasan mitra terhadap solusi dalam mengembangkan usahanya sangat tinggi. Kepuasan ini diperoleh dari keberhasilan tim PPM antara dosen dan mahasiswa dalam membimbing para mitra selama sebulan dengan pemberian pelatihan dan arahan 
yang disesuaikan dengan kebutuhan masingmasing mitra UMKM. Sehingga kepuasan tersebut dapat berupa edukasi dan praktik langsung dalam menggunakan media sosial dalam menunjang bisnis para mitra UMKM.

d. Peningkatan pengetahuan dan keterampilan mitra pasca pelatihan

Kemampuan baru konsumen dalam mengikuti pelatihan dalam bentuk pemantauan terhadap transaksi yang dilakukan setiap waktu atau real time dan yang bisa diakses oleh para mitra UMKM secara online. Hal ini dikarenakan para mitra UMKM berada di 20 tempat berbeda. Pemantauan menunjukkan bahwa ada peningkatan pengetahuan dan keterampilan para mitra. berarti selama pelatihan Pengembangan UMKM berlangsung, pengetahuan dan keterampilan para mitra UMKM dapat meningkat. Selama berlangsungnya pelatihan, setiap mitra akan diawali dengan wawancara terkait dengan kebutuhan yang diinginkan dalam mengembangkan bisnisnya. Setelah itu, baru dilakukan pelatihan berupa digital marketing yang disesuaikan jenis media sosial yang ingin digunakan. Selain itu, hal ini dikarenakan team-work dari tim PPM selama pelatihan berlangsung.

e. Pengaruh digital marketing pada Pengembangan UMKM saat ini

Pemasaran digital adalah pemasaran menggunakan internet untuk sebagai media pemasaran. Pemasaran digital sangat

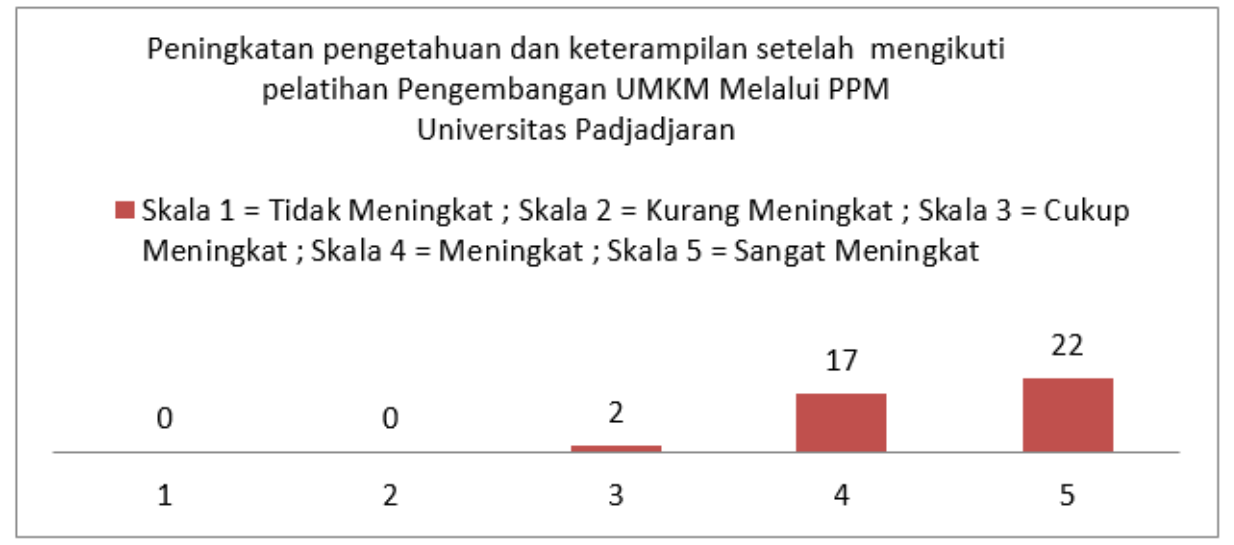

Gambar 9. Peningkatan Pengetahuan dan Keterampilan Mitra Pasca Pelatihan

Berdasarkan hasil evaluasi dan pemantauan di atas, dapat diketahui bahwa sebesar 53,65\% memilih skala 5. Hal ini membantu mitra UMKM karena kemampuan baru dalam mengikuti arus digitialisasi. Sehingga pengaruh yang diberikan pun sangat baik meningkatkan

Pengaruh digital marketing pada Pengembangan UMKM saat ini

Skala 1 = Tidak Meningkat ; Skala 2 = Kurang Meningkat ; Skala 3 = Cukup

Meningkat ; Skala 4 = Meningkat ; Skala 5 = Sangat Meningkat

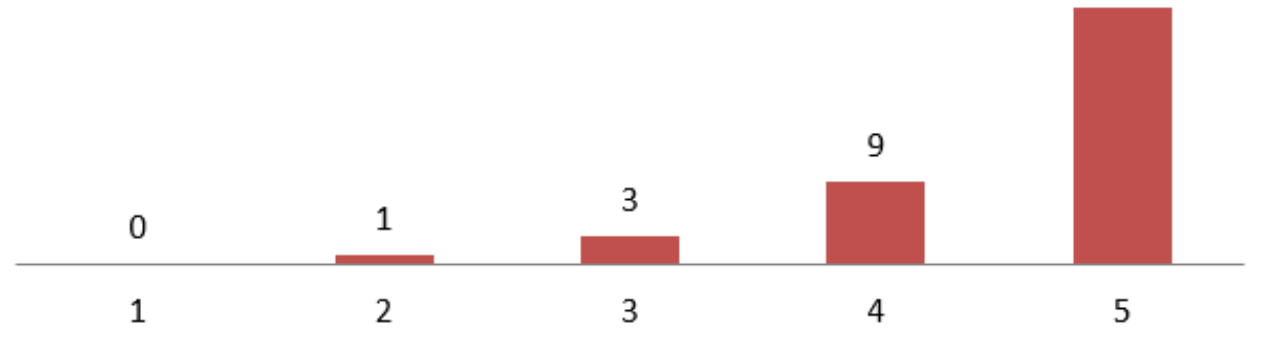

Gambar 10. Pengaruh Digital Marketing pada Pengembangan UMKM Saat Ini 
penjualanan produk yang dimiliki oleh para mitra UMKM.

Berdasarkan hasil evaluasi di atas, dapat diketahui bahwa sebesar 68,29\% memilih skala 5 untuk pengaruh digital marketing pada pengembangan UMKM saat ini. Pengaruh digital marketing oleh para mitra UMKM sangat dirasakan terhadap pengembangan usahanya, terutama dari segi pemasaran dan penjualanan. Hal ini dibuktikan dari pengetahuan dan penggunaan media sosial yang digunakan oleh para mitra UMKM cukup tinggi. Terutama dengan menggunakan Instagram sebagai salah satu media sosial yang sering digunakan para mitra UMKM untuk dapat menunjang pemasaran dan penjualanan produk. Selain itu digital marketing dapat digunakan dalam mempermudah promosi dengan pembuatan profil usaha para mitra UMKM.

\section{SIMPULAN DAN REKOMENDASI}

\section{Pandemi Covid-19 sangat} berpengaruh terhadap perekonomian Indonesia, termasuk UMKM. Dampak tersebut tidak terbatas aspek produksi tetapi juga aspek pemasaran. Pada saat yang bersamaan, banyak UMKM yang belum memahami teknik digital marketing yang efektif sebagai solusi di masa pandemi ini. Kegiatan pelatihan secara virtual dimaksudkan untuk membantu mitra dalam memanfaatkan teknik digital marketing seperti meningkatkan pemasaran melalui media sosial, online advertising, dan branding. Berdasarkan hasil evaluasi menunjukkan bahwa optimalisasi penggunaan dan pemanfaatan media digital telah mampu meningkatkan pengetahuan dan keterampilan mitra dan memberikan dampak pada peningkatan pemasaran

Pelatihan pemanfataan media digital dalam pengembangan UMKM terbukti bermanfaat dan dapat meningkatkan pengetahuan dan keterampilan mitra. Oleh karena itu, direkomendasikan agar metode pendampingan kepada mitra yang berkelanjutan untuk dapat menjadi solusi dalam meningkatkan skala bisnis dan juga siap untuk melakukan adaptasi perusahaan guna meningkatkan skala usaha sekaligus menjaga kelangsungan usaha. Rekomendasi lainnya adalah peningkatan materi lebih tinggi (advance) untuk pelatihan selanjutnya. Dengan demikian peserta dapat mengetahui lebih jauh strategi pemasaran yang tepat dengan branding serta digitalisasi produk, baik selama maupun pandemi dan sesudah masa pandemi.

\section{UCAPAN TERIMAKASIH}

Ucapan terima kasih disampaikan kepada Direktorat Riset dan Pengabdian Masyarakat Universitas Padjadjaran yang mendukung pendanaan kegiatan ini dan para mahasiswa peserta KKNM Integratif Semester Ganjil 2020-2021 atas dukungan selama kegiatan proses pengumpulan data.

\section{DAFTAR PUSTAKA.}

Adi, M Kwartono. 2007. Analisis Usaha Kecil dan Menengah. Yogyakarta:Andi Offset.

Alegre, J., \& Chiva, R. (2013). Linking

Entrepreneurial Orientation and Firm

Performance: The Role of Organizational Learning Capability and Innovation Performance. Journal of Small Business Management, 51(4), 491-507. https://doi.org/10.1111/jsbm.12005

Amri, A. (2020). Dampak COVID-19 Terhadap UMKM Di Indonesia. Jurnal Brand, 2 (1) hal 123-130 .

Asmaya, F. (2015). Pengaruh penggunaan media sosial facebook terhadap perilaku prososial remaja di kenagarian koto Bangun. Jom FISIP, hal 1-15.

Bala, M., \& Verma, D. (2018). A Critical Review of Digital Marketing. International Journal of Management, 8(10), pp 321-339.

Han, Z., and J. Nigg. 2011. The influences of business and decision makers' characteristics on disaster preparedness-A study on the 1989 Loma Prieta Earthquake. International Journal of Disaster Risk Science 2(4) pp 22-31. 
Irwansyah. 2011. Corporate and Marketing Communication. Jakarta: Puskombis Universitas Mercu Buana.

Irmawati, D. (2011). Pemanfaatan E-commerce Dalam Dunia Bisnis. Jurnal Ilmiah Orasi Bisnis Edisi Ke-VI (November), hal 95112.

Kotler, Philip And Gary Armstrong., 2018., Principle Of Marketing, 17e Global Edition, Pearson Education Limited, New York.

Kossyva, D., Sarri, K., \& Georgopoulos, N. (2014). Co-opetition: a Business Strategy for Smes in Times of Economic Crisis. South-Eastern Europe Journal of Economics, 12(1), pp 89-106

Linnenluecke, M., \& Griffiths, A. (2010). Beyond Adaptation: Resilience for Business in Light of Climate Change and Weather Extremes. Business \& Society, 49(3), pp 477-511. https://doi.org/10.1177/0007650310368 814

Liu, Z., Xu, J., \& Han, B. T. (2013). Small- and medium-sized enterprise post-disaster reconstruction management patterns and application. Natural Hazards, 68(2), pp 809-835.

McLuhan, Marshall. 2011. Understanding Media. London: Routledge Classics.

McQuail, Denis. 2011. Teori Komunikasi Massa. Jakarta: Salemba Humanika.

Muhammad, Sy. (2020). Dampak Pandemi Covid-19 Terhadap UMKM di Indonesia. $\mathrm{NU}$

Online. https://www.nu.or.id/post/read/123247/d ampak-pandemi-Covid-19-terhadapumkm-di-indonesia (diakses pada 30 Desember 2020)

Murdjito. G. (2012), Metode Pengabdian Masyarakat. Disampaikan pada Pelatihan Metodologi Pengabdian kepada Masyarakat. https://www.slideshare.net/FitriRiyanto/ metoda-pengabdian-pada-masyarakatpak-gatot1, diakses 25 April 2021

Nadya (2016) Peran Digital Marketing dalam Eksisten Bisnis Kuiner Seblak Jeletet Murni. Jurnal Riset Manajemen dan Bisnis, 1 (2), hal 133-144

Oktaviani, F. dan Rustandi, D. (2018).
Implementasi Digital Marketing dalam Membangun Brand Awareness. Jurnal PRofesi Humas, 3(1), hal 1-20

Pratiwi, M.I. (2020). Dampak COVID-19 Terhadap Perlambatan Ekonomi Sektor UMKM. Jurnal Ners, 4 (2), hal 30 - 39.

Raharja, S.J. dan Adiprihadi, D. (2020). Dampak Pandemik Covid-19 Terhadap UMKM di Kota Bandung. Laporan Akhir Penelitian.

Rudjito. (April 2003). Strategi pengembangan UMKM Berbasis Sinergi Bisnis, dalam Makalah yang disampaikan pada seminar peran perbankan dalam memperkokoh ketahanan nasional kerjasama Lemhanas RI dengan BRI

Sugiarti, Y., Sari, Y., \& Hadiyat, M. A. (2020). Peranan E-Commerce untuk Meningkatkan Daya Saing Usaha Mikro Kecil dan Menengah (UMKM) Sambal di Jawa Timur. Jurnal Kumawula: Jurnal Pengabdian Kepada Masyarakat, 3(2), 298-309.

https://doi.org/https://doi.org/10/24198/k umawula.v3i2.28181

Susanti, S., Gunawan, W., \& Sukaesih, S. (2019). Pengembangan Pemasaran Bordir dan Kelom Geulis Tasikmalaya Melalui Media Sosial. Jurnal Kumawula: Jurnal Pengabdian Kepada Masyarakat, 2(3), 248-261. https://doi.org/http://10.24198/kumawul a.vli3.25256

Suswanto, P dan Setiawati,S. D., (2020). Membangun Strategi Komunikasi Pemasaran dalam Membangun Positioning di Tengah Pandemi Covid-19 di Indonesia. Lini Masa: Jurnal Ilmu Komunikasi, 3(2), hal 16-29.

Tambunan, T.H. (2012) Usaha Mikro Kecil dan Menengah di Indonesia: Isu-Isu Penting, Jakarta: LP3ES

Yacub, R. dan Mustajab, W. (2020). Analisis Pengaruh Pemasaran Digital (Digital Marketing) Terhadap Brand Awareness pada E-Commerce. Manajerial : Jurnal Manajemen dan Sistem Informasi, 12(2), hal 198-209

Zarella, D (2011). The Social Media Marketing Book. Sebastopol. Reilly Media Inc. 